DEPARTMENT OF THE INTERIOR

U.S. GEOLOGICAL SURVEY

An Evaluation and Geochemical Survey of the Farah Garan East Prospect, Southeast Asir, Kingdom of Saudi Arabia

By Arthur A. Bookstrom, M.B. E1-Komi, and Ralph P. Christian

with a section of

A Ground Electromagnetic Geophysical Survey

By Maher A. Bazzari

Open-File Report $90-421$

Report prepared by the U.S. Geological Survey in cooperation with the Deputy Ministry for Mineral Resources, Saudi Arabia

This report is preliminary and has not been reviewed for conformity with U.S. Geological Survey editorial standards and stratigraphic nomenclature.

1/ USGS Saudi Arabian Mission 


\title{
AN EVALUATION AND GEOCHEMICAL SURVEY OF THE FARAH GARAN EAST PROSPECT, SOUTHEASTERN ASIR, KINGDOM OF SAUDI ARABIA
}

\author{
By \\ Arthur A. Bookstrom, Mohammed B. El-Komi, \\ and Ralph P. Christian \\ With a section on
}

A GROUND ELECTROMAGNETIC GEOPHYSICAL SURVEY

By

Maher Bazzari

\section{ABSTRACT}

The Farah Garan East prospect (MODS 4886) is located in the southeastern part of the Precambrian Arabian Shield of Saudi Arabia, about $15 \mathrm{~km}$ east-northeast of Zahran Al Janub and $1 \mathrm{~km}$ northeast of the ancient mines at Farah Garan. Ore minerals at the Farah Garan East prospect are pyrite, tennantite, galena, and sphalerite. These are sparsely and erratically distributed in west-dipping beds of dolomite, dolomite-talc breccia, and carbonate-sericite phyllite, and in associated breccias and zones of carbonate-altered mafic metavolcanic rocks, all of Precambrian age. Concordant beds of dolomite and carbonate-sericite phyllite are interlayered with metavolcanic rocks and are interpreted as volcanic-related submarine hydrothermal deposits of Precambrian age. Funnel-shaped bodies of dolomite-talc breccia that crop out near the north and south ends of the dolomite beds are interpreted as submarine hot-spring vent breccias. Aprons of exhalative dolomite thin laterally outward from these vents. Discordant and concordant zones of carbonate-altered metavolcanic rocks, east of and structurally below the hot-spring vents, probably represent pathways of hydrothermal circulation along networks of fractures in volcanic rocks, subjacent to these Precambrian submarine hot-spring vents.

Ore minerals in outcrops, and geochemically anomalous concentrations of gold, silver, copper, lead, zinc, arsenic, antimony, and tellurium are present in carbonate-rich rocks of the hot-spring assemblage. This indicates that the ore minerals and elements were deposited originally as constituents of the hot-spring assemblage. However, exposed ore-mineral occurrences are small and sparse, and geochemical anomalies are small, irregularly distributed, and of subeconomic grade. Furthermore, weak electromagnetic anomalies do not indicate the presence of subsurface bodies of concentrated, conductive ore minerals. Therefore, no drilling is recommended. 


\section{INTRODUCTION}

\section{Location and Access}

The Farah Garan East prospect (MODS 4886) is located in southwestern Saudi Arabia, in the southeastern part of the Late Proterozoic Arabian Shield of Saudi Arabia. Farah Garan East lies east of the Red Sea escarpment, in the southeastern Asir, about halfway between Abha-Khamis Mushayt and Najran (Fig. 1), and about $15 \mathrm{~km}$ (linear distance) east-northeast of Zahran Al Janub (Fig. 2, "Z"). As indicated by the coordinate system of the 1:100,000-scale photomosaic map of Tihama-Asir, Farah Garan East is located at approximately $17^{\circ} 40^{\prime} 54^{\prime \prime} \mathrm{N}$., $43^{\circ} 38^{\prime} 30^{\prime \prime} \mathrm{E}$. However, as indicated by the coordinate system of the 1:50,000-scale topographic map of the Zahran Al Janub quadrangle, Farah Garan East is located at approximately

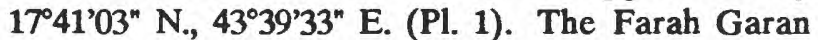
East prospect is located about $1 \mathrm{~km}$ northeast of the ancient mines of Farah Garan (Fig. 2), which are accessible via $25 \mathrm{~km}$ of dirt roads leading from Talhah, which is located about $10 \mathrm{~km}$ north of Zahran Al Janub. Farah Garan East is accessible by following the course of an unnamed canyon, the upper end of which is located about $0.5 \mathrm{~km}$ north of the ancient workings at Farah Garan. A footpath leading about $0.5 \mathrm{~km}$ eastward, down the wadi in the bottom of this canyon, intersects a lens of dolomitic marble, which is the exhalative dolomite of the Farah Garan East prospect.

\section{Purpose}

The purpose of this project was to evaluate the exploration potential of the Farah Garan East prospect for precious metals in combination with base metals. This was done on the basis of geological, geochemical, and geophysical surveys conducted at the surface in order to determine whether the prospect should be tested by drilling, and if so, where.

\section{Methods}

The geology of the study area was mapped on a topographic base, enlarged to 1:2,000 scale from the 1:50,000-scale topographic map of the Zahran Al Janub quadrangle (sheet 4317-13). Geologic features were mapped by tape and compass traverses referenced to a base line along the axis of the prospect (N. $16^{\circ}$ E.). A $50-\mathrm{m}$ grid was later established for control of the accompanying geophysical survey. Nine rock-chip geochemical sampling traverses were conducted across the trend of the prospect. Semicontinuous chip-channel samples were collected across 1283 -m intervals. The samples were analyzed at the USGS/DGMR chemical analytical laboratory, under the supervision of Technical Advisor K.J. Curry, using $\mathrm{HBr} / \mathrm{Br}$ digestion, MIVK organic extraction, and atomic absorption techniques. Gold analyses were re-run at Skyline Labs, Inc., Wheat Ridge, Colorado, because the high carbonate content of some samples caused difficulties with the organic extraction of gold. The gold assays presented here are from Skyline Labs, Inc.; assays for other elements are from the Jeddah USGS/DGMR laboratory.

Petrographic thin sections were examined to check preliminary field identifications of rocks and minerals. Mir. Amjad Hussain (USGS) analyzed tennantite samples, using the JEOL-T300 scanning electron microscope (equipped with energy dispersive $\mathrm{Si}(\mathrm{Li}) \mathrm{X}$-ray detector analysis system and Tracor Northern Computer). Identifications of clinochlore, talc, and nimite were done by I.M. Naqvi (USGS) by $\mathrm{X}$-ray diffraction, using Phillips software and an automatic powder-diffraction system PW1700 with monochromator and proportional detector used to search for and identify the minerals. Minerals identified by the best-fit method were checked and compared graphically and manually using Hanawalt and Fink search manuals in the powder-diffraction file.

\section{ACKNOWLEDGMENTS}

This work was conducted in accordance with the Ninth Extension to the Work Agreement between the Saudi Arabian Directorate General of Mineral Resources (DGMR), Jeddah, Saudi Arabia, and the United States Geological Survey (USGS) Saudi Arabian Mission under Subproject 3.11.28. Field support was provided by camp boss Mageet $\mathrm{Al}$ Qatani (USGS) and his crew. The geophysical grid was surveyed by Said Liban (USGS). Thin sections were made in the USGS/DGMR Petrography Laboratory, under supervision of Abdulraquib Turkistani (DGMR). The manuscript was typed by R.M. Boquiren and reviewed by K.A. Sargent. The USGS Technical Reports Unit staff provided editing, drafting, and production support.

\section{PREVIOUS WORK}

R.E. Anderson discovered the ancient workings of Farah Garan in 1974 (Anderson, 1979). In 


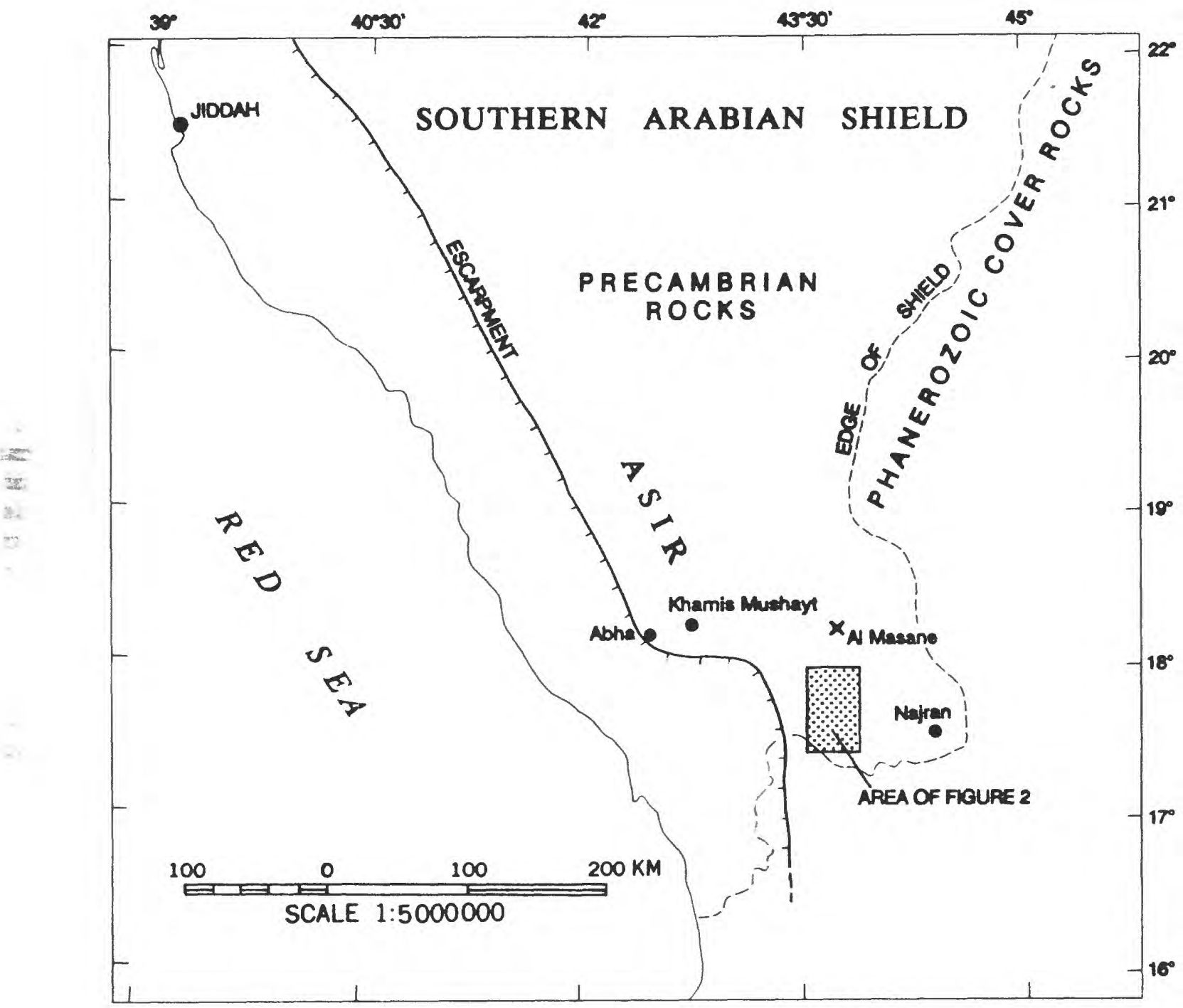

Figure 1.-Location map. 


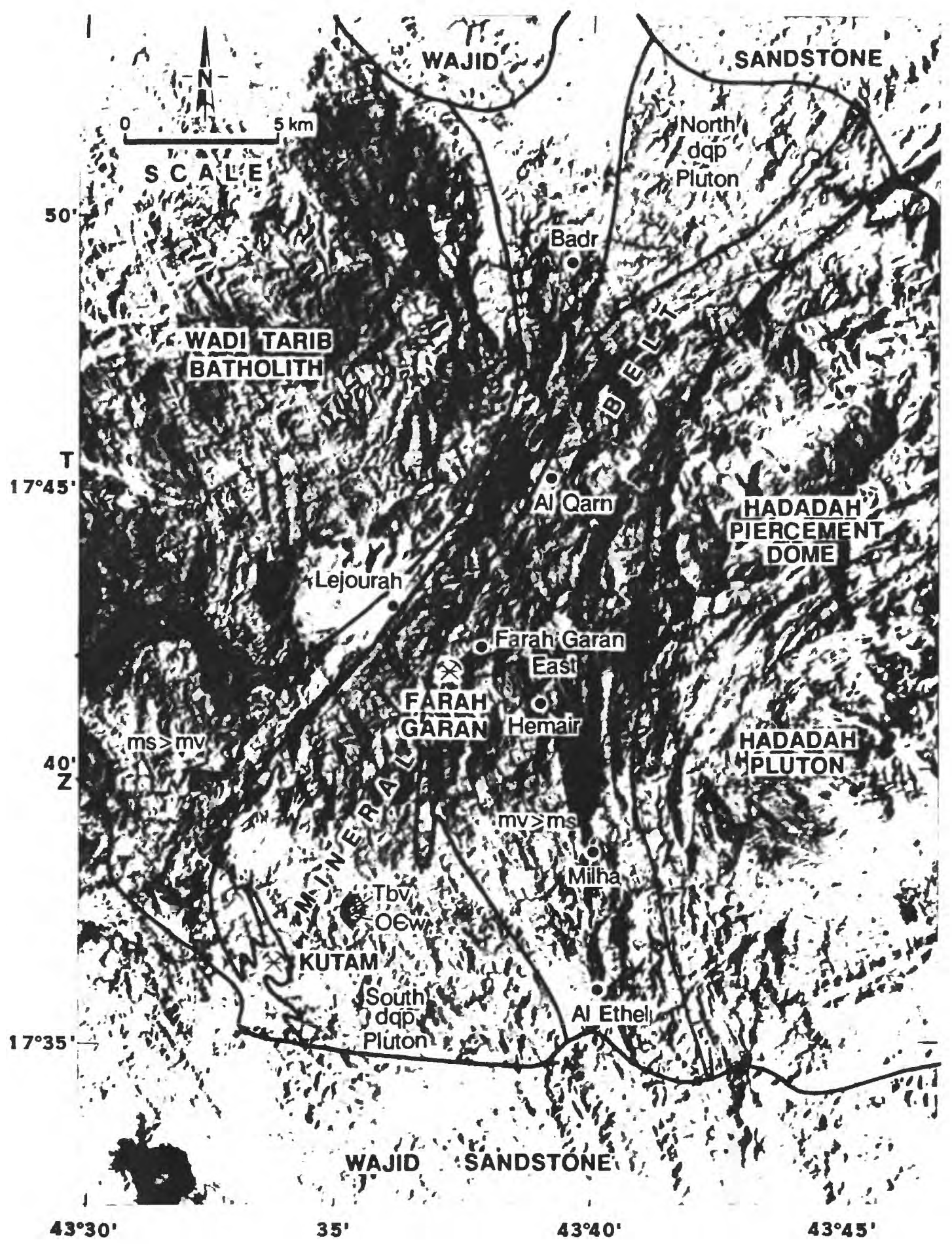

Figure 2.--Landsat thematic-mapper image (band-7) of Farah Garan - Kutam mineral belt showing approximate locations of Zahran Al Janub (Z), Talhah $(T)$, and selected prospects and major geological features $(\mathrm{mv}=$ metavolcanic rocks, $\mathrm{ms}=$ metasedimentary rocks, dqp = dacitic quartz porphyry, OEw = Cambrian-Ordovician Wajld Sandstone, and Tbv = Tertiary basaltic volcanic rocks). 
1975-76, C.W. Smith mapped the Farah Garan prospect and conducted rock-chip sampling; H.R. Blank conducted geophysical surveys. This work, and the preliminary conclusion that the mineralization was epigenetic and controlled by shear zones along marble contacts, was reported in Smith (1979). In 1978-79, three core holes were drilled (Smith and Mawad, 1982). Drill hole FG-3 intersected an $8.55-\mathrm{m}$ gold-rich interval containing $8.67 \mathrm{ppm} \mathrm{Au}$, $18.51 \mathrm{ppm} \mathrm{Ag}, 0.29$ percent $\mathrm{Cu}, 0.18$ percent $\mathrm{Pb}$, and 3.18 percent $\mathrm{Zn}$. Smith and Mawad (1982, p. 35) noted that "sulfides occur as conformable layers within volcanic rocks and as stringers, irregularly shaped masses, disseminations, and wisps in intensely altered fault breccias." They concluded that "original sulfides probably were deposited under volcanogenic conditions and later modified by shearing and continuing hydrothermal activity."

The Farah Garan East prospect was discovered as a result of a wadi-sediment geochemical survey for base metals conducted by Riofinex (1978). Parker (1982) made a geologic map of the prospect and collected 22 rock-chip samples, 6 of which contained $>1 \mathrm{ppm} \mathrm{Au}$ and one of which contained $16 \mathrm{ppm}$ Au. However, Parker noted that surface exposures of mineralized rocks at Farah Garan East are very small and erratically distributed, and therefore he recommended no further work.

In 1984, Arabian Shield Development Company announced the presence of economically mineable deposits of zinc-copper-gold-silver ore at Al Masane (Fernette and Al Tawil, 1984). Al Masane is about $55 \mathrm{~km}$ north-northeast of Farah Garan, and the deposits of Al Masane, as described by Fernette and Al Tawil (1984) and Conway (1984) are similar to those of Farah Garan, as described by Smith and Mawad (1982). At both Al Masane and Farah Garan, stratiform sulfide deposits occur in dolomitic beds, which are conformably interlayered with steeply-dipping metavolcanic and metasedimentary rocks of the Malahah belt of Greenwood and others (1982) and(or) the Habawna fold belt of Conway (1984).

The high price of gold in the 1980's, the previous discovery of gold in drill hole FG-3 at Farah Garan, and the similarities between Al Masane and Farah Garan led to a decision to reexamine Farah Garan and other prospects of the Farah Garan Kutam mineral belt. This work began in 1987 and results appear in Doebrich (1989), Samater and others (1989), Kellogg and others (1989), Bookstrom and others (1989), and in this report.

\section{Exploration Rationale}

Farah Garan East was reexamined in 1988, as drilling was in progress at Farah Garan. Volcanic-related sulfide deposits tend to occur in clusters, and the lenses of exhalative dolomite at Farah Garan East resemble those at Farah Garan and Al Masane. Furthermore, Parker (1982) reported a few ore-grade gold assays obtained from rocks at Farah Garan East. The geologic, geochemical, and geophysical surveys reported herein were conducted to test whether the exposed, visible, and sparsely disseminated ore minerals of Farah Garan East represent geochemically detectable (but not visible) ore-grade gold and(or) subsurface concentrations of conductive ore minerals likely to be associated with gold.

\section{GEOLOGY}

Plate $1 \mathrm{~A}$ is a $1: 2,000$ scale map showing the geology of the Farah Garan East prospect. The accompanying description of map units gives brief descriptions of the lithologic units at Farah Garan East. For a map and description of the geologic setting of Farah Garan East, see Bookstrom and others (1989, Plates 1 and 2). For a description of the drilling project at Farah Garan, see Doebrich (1989). For a description of a wadi-sediment geochemical survey of the Farah Garan - Kutam mineral belt, see Samater and others (1989).

Mafic metavolcanic rocks (map units $\mathrm{mv}$, mvc, and mvp on Plate 1A) are the predominant lithologic units surrounding the Farah Garan East prospect. They are metamorphosed to greenschist facies and commonly are partially to completely replaced by carbonate minerals along concordant and discordant fracture zones. Layering and foliation in these rocks generally strike north-northeast and dip steeply west-northwest. West-facing pillow structure, recognizable locally in metabasalt, indentifies submarine basalt flows, which have west-facing depositional tops.

Concordant lenses of volcanic-exhalative dolomite (map unit vxd on Plate 1A) and beds of volcanic-hydrothermal carbonate-sericite phyllite (vhs) occupy the long axis of the Farah Garan East prospect. Like the mafic metavolcanic rocks below and above them, these lenses and layers strike north-northeast and dip steeply west-northwest. 
Thus, the steeply dipping strata presently exposed in map view represent a west-dipping stratigraphic succession, with up-section direction to the west.

At Farah Garan East, dolomite beds crop out over a strike length of about $500 \mathrm{~m}\left(\mathrm{~N} .16^{\circ} \mathrm{E}\right.$.). Near the north and south ends of the dolomite beds are zones of dolomite-talc breccia (dtbx). These breccia zones are crudely funnel-shaped in cross section (as now exposed in map view). They are underlain, overlain, and(or) flanked by beds and lenses of volcanic exhalative dolomite (vxd) that thin laterally outward from the breccias. The breccias are interpreted as submarine hot-spring vent breccias, and the dolomite beds and lenses are interpreted as aprons of carbonate-rich hot-spring deposits. Vent-facies accumulations of dolomite and dolomite-talc breccia are underlain by steep, discordant zones of carbonate-altered mafic metavolcanic rocks [mv(ca)]. These are interpreted as chimney-like hydrothermal feeders along steep fractures beneath the vents. At deeper levels, these connect with a large-scale network of both concordant and discordant zones of carbonatealtered metavolcanic rocks. This network defines the hydrothermal plumbing system beneath the volcanicrelated submarine hot-springs of Farah Garan East.

Relatively extensive layers of carbonate-sericite phyllite (vhs) generally surround lenses of volcanicexhalative dolomite. In addition to siderite, pyrite, and sericite, interpreted as kydrothermal, the phyllites of these layers contain relict quartz and feldspar phenocrysts, suggestive of a felsicvolcaniclastic source component. Foliation in these phyllites is foliated parallel to layering and foliation in mafic metavolcanic rocks stratigraphically above and below them. Because they have the same metamorphic and tectonic history as their metavolcanic host rocks, these carbonate-sericite phyllites are interpreted as synvolcanic in age, probably representing felsic volcaniclastic layers selectively altered and replaced by hydrothermal fluids associated with volcanic-related submarine hot springs.

Volcanic-exhalative dolomite (vxd) crops out over a strike length of about $500 \mathrm{~m}$ at Farah Garan East (Plate 1A). Funnel-shaped bodies of breccia indicate the presence of hot-spring vents near the north and south ends of this $500-\mathrm{m}$ strike length. Traverse $T-1$, located near the north end of the exhalative dolomite, crosses a thick, short lens of dolomite (vxd, $20 \times 70 \mathrm{~m})$, north of a funnel-shaped body of vent breccias of three types: 1) dolomite breccia (dbx); 2) dolomite-talc breccia (dtbx); and 3) quartz breccia ( $q b x)$. Traverse $T-7$ begins in dolomite (vxd) of the northern dolomite lens and passes downward, through breccia (dbx), and into carbonate-sericite phyllite (vhs). Traverse T-9 is located on the south side of the vent breccias of the northern hot-spring vent. It crosses two lenses and one layer of dolomite. The thick bottom lens correlates with the northern (T-1) dolomite lens but is separated from it by vent breccias. The middle layer of dolomite overlaps the top. of the northern vent breccias and pinches out above them. To the south, this middle layer of dolomite varies in apparent thickness ( 2 to $10 \mathrm{~m}$ ), as it curves about 115 $m$ to the south. There it connects with a southward-thickening layer of dolomite, which is traceable another $115 \mathrm{~m}$ south, to a thick lens of dolomite and dolomite-talc breccia at T-2, located near the south end of the prospect. The upper lens of dolomite (at traverse T-9) is thin and pinches out to the north and south. The dolomite beds of traverses T-1 and T-9 are interpreted as aprons of exhalative dolomite, located to the north and south of the northern hot-spring vent. The three dolomite beds of traverse T-9 indicate that submarine hot-spring activity of the northern vent increased and decreased three times.

Traverses T-2 and T-5, located near the south end of the Farah Garan East prospect, cross a funnel-shaped body of exhalative dolomite (vxd) and vent-facies dolomite-talc breccia (dtbx), (Plate 1A). At its thickest part, just north of T-2, this body of dolomite and dolomite-talc breccia is about $60 \mathrm{~m}$ thick. To the south, this hot-spring vent-facies assemblage pinches out less than $100 \mathrm{~m}$ south of T-2. To the north, vent breccia ends at a west-northwest-striking fault. North of this fault, a layer of exhalative dolomite extends northward, thinning from about $18 \mathrm{~m}$ thick at traverse T-6 to about $4 \mathrm{~m}$ thick, $10 \mathrm{~m}$ to the north of traverse T-8. There the north dolomite apron of the south hot-spring vent connects with the middle dolomite layer of the south apron of the northern hot-spring vent.

Traverse 2 begins at the top of the funnelshaped hot-spring vent. It extends eastward (stratigraphically and structurally downward) through vent-facies dolomite-talc breccia (dtbx) and volcanic-exhalative dolomite (vxd), and down the 
throat of the pipe-like zone of carbonate-altered metavolcanic rocks [mv(ca)] beneath the hot-spring vent. This zone of carbonate-altered rocks probably represents a zone of steep fractures that served as a chimney for upward-convecting brines, heated by interaction with cooling volcanic and subvolcanic rocks below.

Ore minerals are sparsely disseminated in dolomite (vxd), dolomite-talc breccia (dtbx), carbonate-sericite phyllite (vhs), and in adjacent carbonate-altered rocks (ca). Ore minerals identified in the field and by scanning electron microscopy are pyrite, tennantite (with about $20 \mathrm{wt}$. percent of As, 5 wt. percent of $\mathrm{Sb}$, and traces of silver), galena, sphalerite, and malachite. Thin limonite coatings are ubiquitous, but there are no gossanous concentrations of abundant limonite. Spots of malachite are sparsely scattered. These commonly are weathering products of tennantite, which occurs as sparsely scattered grains in dolomite and dolomite-talc breccia, as well as in minor quartz veins and talcose fractures in those rocks. Small crystals of galena, sphalerite, and tennantite also are sparsely scattered in carbonate-altered rocks of the hot-spring feeder beneath the south dolomite lens. Gangue and(or) alteration minerals are dolomite, calcite, siderite, quartz, talc, sericite, clinochlore, and nimite (a nickel-bearing chlorite).

\section{ROCK-CHIP GEOCHEMICAL SURVEY}

Nine rock-chip geochemical-sample traverses are shown on Plate 1A (traverses T-1 through T-9). Each sample consists of rock chips collected along a 3-m chip-channel interval. On Plate 1A, sample intervals are indicated by tick marks along lines representing the sample-traverses. Three-digit sample numbers shown on the map are the last three digits of 6-digit RASS numbers of the 237,000 series, as listed in the tables to the left of the maps.

Each sample was analyzed for gold and silver, for pathfinder elements (arsenic, antimony, and tellurium) commonly associated with precious-metal deposits, and for base metals (copper, lead, and zinc) commonly associated with gold in volcanic-exhalative deposits. Frequency-distribution diagrams for each element (Fig. 3) define local anomaly thresholds for gold (about $0.5 \mathrm{ppm}$ ), arsenic (about $90 \mathrm{ppm}$ ), antimony (about $50 \mathrm{ppm}$ ), tellurium (about $8 \mathrm{ppm}$ ), silver (about $10 \mathrm{ppm}$ ), copper (about $400 \mathrm{ppm}$ ), lead (about $800 \mathrm{ppm}$ ), and zinc (about 3,000 ppm).

Tabular listings of geochemical data for the 128 samples collected from traverses 1 through 9 are given in Table 1 (Pl. 1). Samples with $0.5 \mathrm{ppm}$ (or more) of gold are indicated by barred intervals with adjacent assay results for gold (in $\mathrm{ppm}$ ). All traverses (except T-3 and T-4) extended downsection, from west to east.

Results of the sample traverses are graphically presented in the graphs of Figures $A, 5$, and 6. These are plots of elemental concentrations versus traverse distances, with the predominant rock type of each sample interval noted on the horizontal axis. Traverses 3, 4, and 7 did not include samples containing anomalous concentrations and are, therefore, omitted. All other traverses read from west (stratigraphic top) at the left to east (stratigraphic bottom) at the right. Thus, the sample-traverse assay plots of Figures 4, 5, and 6 can be read as graphic assay logs, with down-section to the right.

In Figure 4, the log for traverse 1 shows that gold is anomalous in exhalative dolomite (vxd). Plate $1 \mathrm{~A}$ shows that this gold anomaly is located $3 \mathrm{~m}$ north of an ancient working. This is a small ancient pit on a talcose fracture that cuts the dolomite and contains minor malachite. Traverse 1 passes north of this, across dolomite that contains no visible ore minerals, but contains geochemically anomalous concentrations of gold, antimony, silver, copper, lead, and zinc (Fig. 4). Arsenic is anomalous in the carbonatesericite phyllite (vhs) above the dolomite. Anomalous concentrations of tellurium and zinc are present in the dolomite (vxd) and the carbonatesericite phyllite (vhs) below it. This lower anomaly is on-strike with small, lower lenses of exhalative dolomite (vxd) to the north.

Traverse 2 (Fig. 4) proceeds down-section through dolomite-talc vent breccia (dbx), exhalative dolomite (vxd), and carbonate-altered rocks [(ca) and $\mathrm{mv}(\mathrm{ca})]$ of the hydrothermal feeder beneath the south dolomite lens. Gold, arsenic, silver, copper, lead, and zinc assays fluctuate near their anomalythreshold concentrations in the dolomite-talc vent breccia (dtbx) and the exhalative dolomite (vxd). Tellurium and antimony concentrations peak near the bottom of the dolomite (vxd). Gold, antimony, arsenic, silver, and base-metal concentrations peak in the carbonate-altered rocks (ca) of the feeder. 

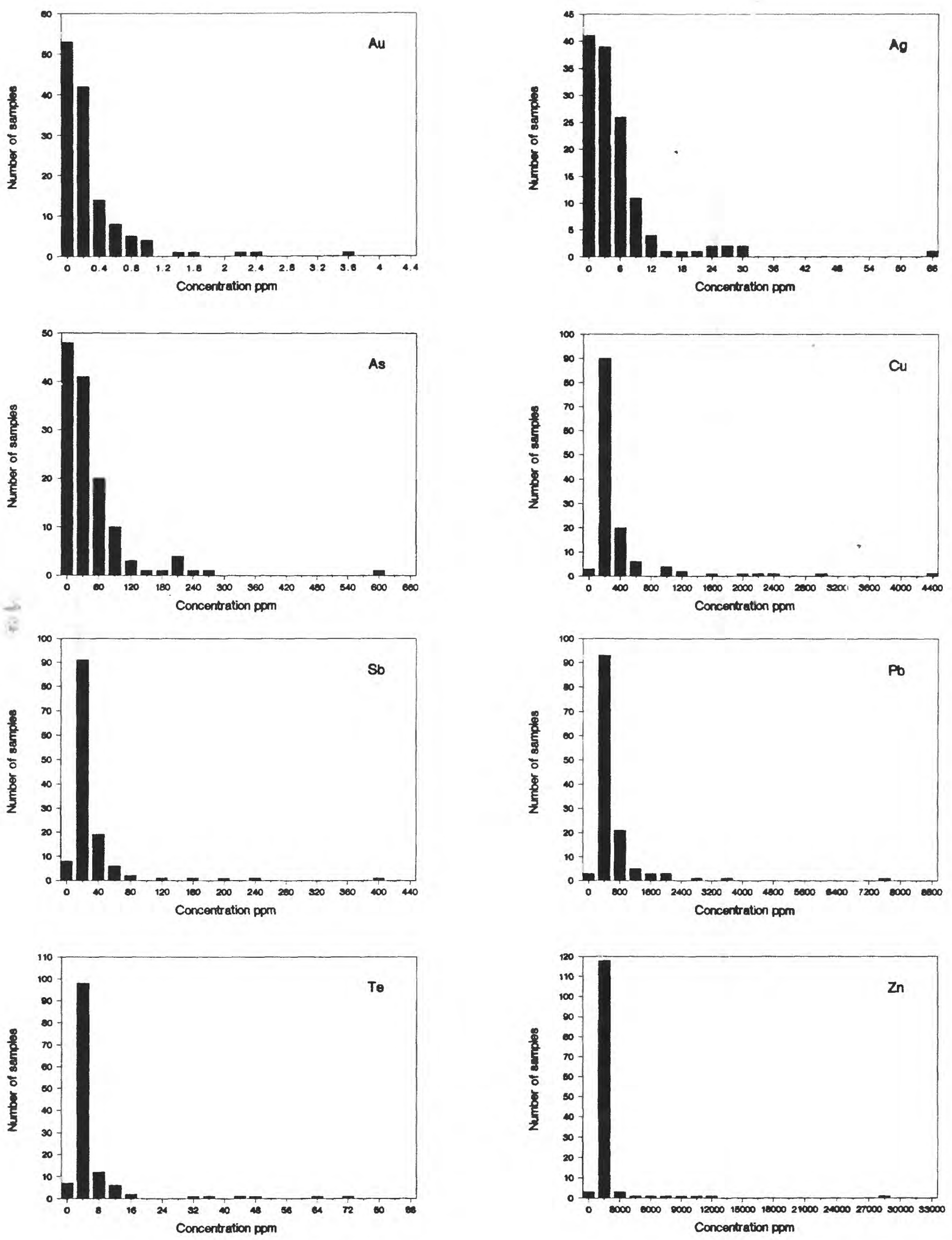

Figure 3.-Frequency distribution diagrams for $\mathrm{Au}, \mathrm{As}, \mathrm{Sb}, \mathrm{Te}, \mathrm{Ag}, \mathrm{Cu}, \mathrm{Pb}$, and $\mathrm{Zn}$. 

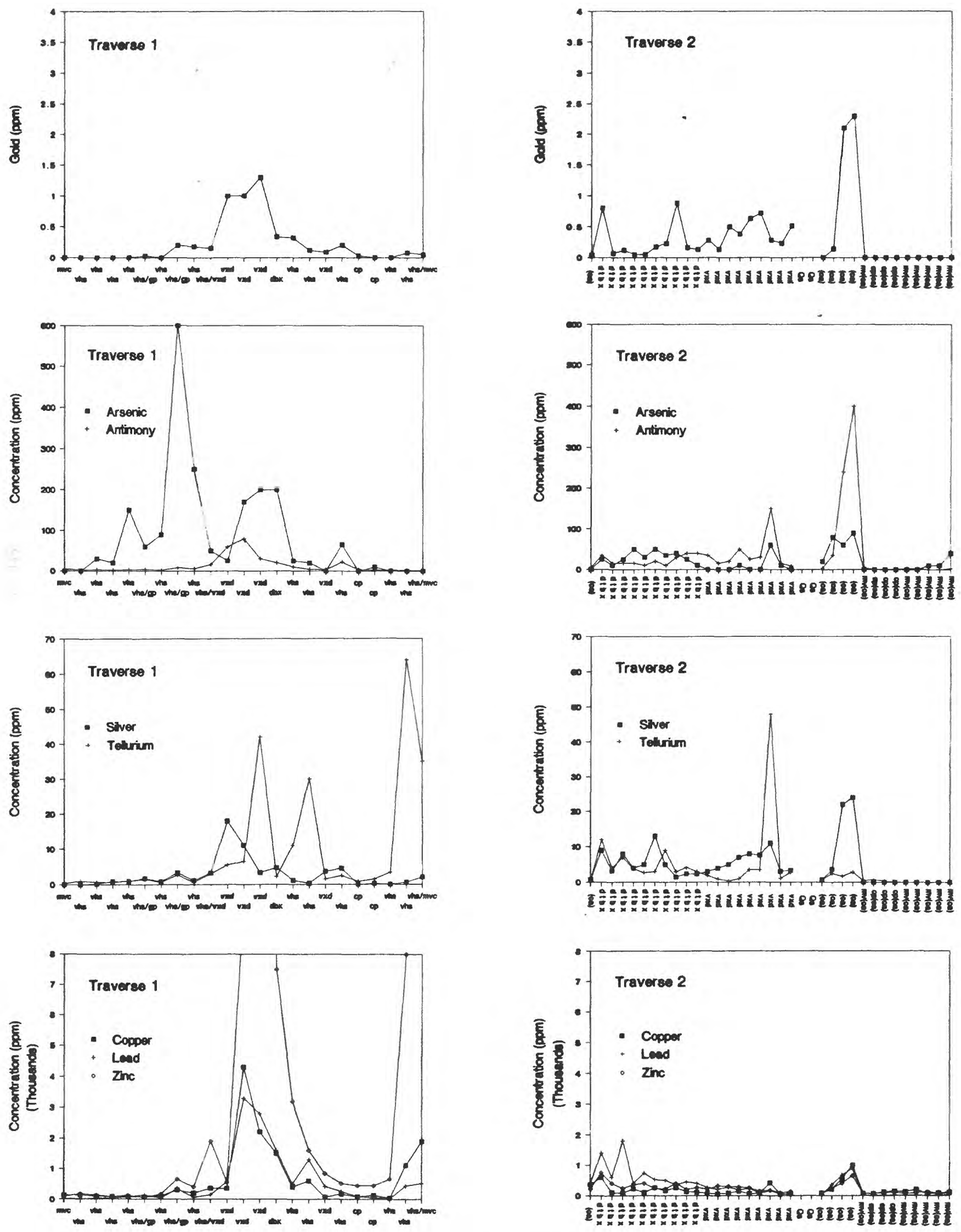

Figure 4.-Piots of element concentrations versus traverse distances (traverses 1 and 2) and rock types. Explanation of thithologic symbols given in description of map units, Plate 1. 

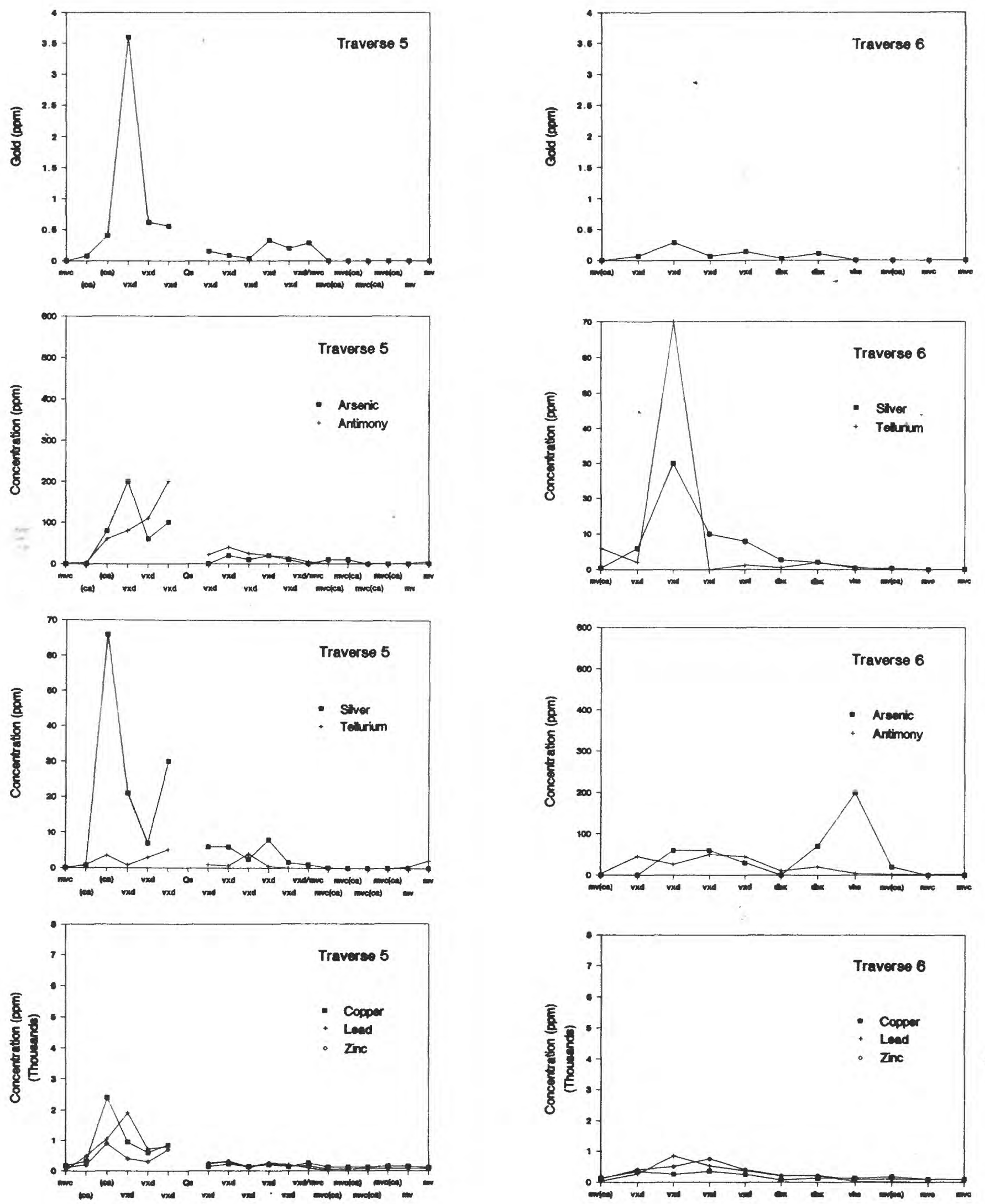

Figure 5.-Plots of element concentrations versus traverse distances (traverses 5 and 6) and rock types. Explanation of lithologic symbols given in description of map units, Plate 1. 

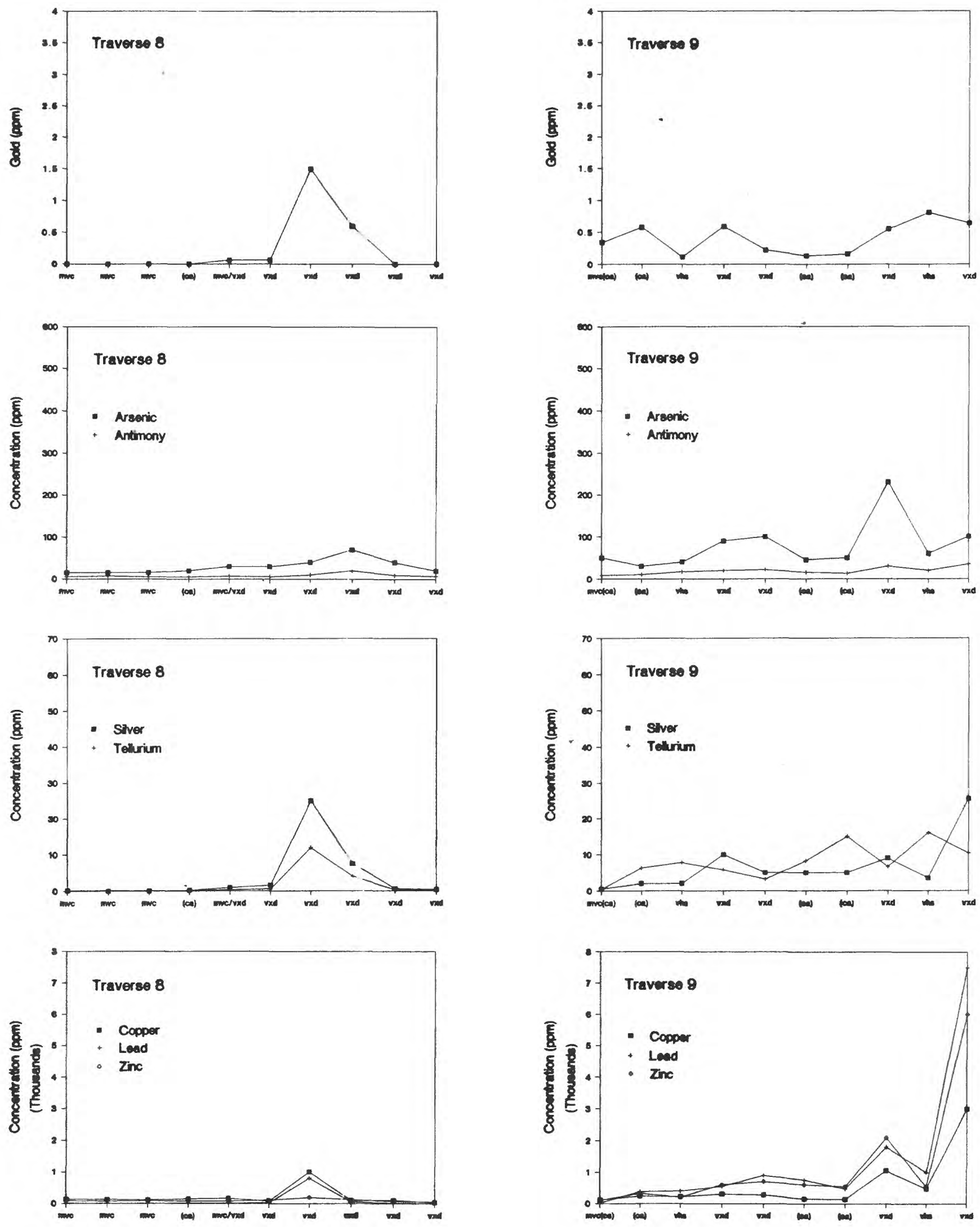

Figure 6.-Plots of element concentrations versus traverse distances (traverses 8 and 9) and rock types. Explanation of lithologic symbols given in description of units, Plate 1. 
In Traverse 5 (Fig. 5), located at the south end of the south lens of exhalative dolomite, gold, arsenic, silver, and base-metal concentrations peak at the top of the exhalative dolomite (vxd) and in the carbonate-altered rock (ca) immediately above it.

In Traverse 6 (Fig. 5), located north of the thickest part of the south dolomite layer, tellurium and silver concentrations peak near the top of the exhalative dolomite (vxd). In the same location, gold, arsenic, antimony, and base-metal concentrations fluctuate near their anomaly thresholds. The concentration of arsenic peaks in carbonate-sericite phyllite (vhs) subjacent to the dolomite.

Traverse 8 (Fig. 6), located near the thinnest part of the dolomite layer connecting the north and south hot-spring vents, contains anomalous concentrations of gold, silver, tellurium, copper, and lead in volcanic exhalative dolomite (vxd).

Traverse 9 (Fig. 6) crosses three beds of exhalative dolomite (vxd), with near-threshold gold anomalies in each dolomite bed, as well as in carbonate-altered rocks (ca), above the uppermost dolomite, and in carbonate-sericite phyllite (vhs), between the middle and lower dolomite beds. The concentration of antimony is highest in the middle dolomite (vxd); concentrations of base metals and silver are highest in the lower dolomite (vxd). The base of this unit is covered by talus.

The highest concentrations of gold, silver, arsenic, antimony, tellurium, and base metals generally are in the following volcanic-related hydrothermal rock types at Farah Garan East: exhalative dolomite (vxd), dolomite-talc breccia (dtbx), carbonate-sericite phyllite (vhs), and strongly carbonate-altered rocks (ca). This indicates that geochemically anomalous concentrations of metals are cogenetic with the carbonate-rich hot-spring deposits in which they occur. However, the occurrence of tennantite in quartz veins that cut dolomite (vxd) and the occurrence of malachite in talcose fractures, which also cut dolomite (vxd), both indicate at least minor remobilization of ore minerals, during metamorphism, deformation, and subaerial weathering of the original submarine exhalative deposits.

\title{
A GROUND ELECTROMAGNETIC GEOPHYSICAL SURVEY AT THE FARAH GARAN EAST PROSPECT, KINGDOM OF SAUDI ARABIA
}

\author{
By \\ Maher A. Bazzari
}

\section{INTRODUCTION}

Electromagnetic surveys were done to test whether the low-grade surface geochemical anomalies of Farah Garan East might be peripheral manifestations of more-massive concentrations of conductive ore minerals in the subsurface.

\section{Principle of the EM Method}

The principle of the electromagnetic exploration method is that if a conductive body of ore minerals is subjected to a primary alternating electromagnetic field, a secondary current is induced in the conductive body, and this develops a secondary magnetic field, opposing the primary one. The two magnetic fields together create a resultant field with amplitude and phase that are different from those of either the primary or secondary fields. These differences are measured as dip (tilt) angle.

\section{Crone Electromagnetic Method}

This method (CEM) (also called Horizontal Shootback Method) is a simple field technique well-suited to the rugged terrain of Farah Garan East, where slope angle between transmitting and receiving coils is highly variable. This method employs two identical coils, each capable of transmitting and receiving. Both coils in turn transmit and then receive in order to measure the dip angle (tilt) of the receiving coil. The two measured tilt angles are then averaged in order to eliminate the effect of elevation difference between the two coils; the result is plotted at the mid-point between coils. The resultant dip angle is usually negative if conductors are detected and more-negative tilt angles indicate the presence of relatively more-conductive materials between the coils. Wider coil spacings and lower frequencies give deeper penetration, although signal strength may also be lowered. 


\section{CEM SURVEY}

The CEM,geophysical survey of Farah Garan East was carried out along N. $74^{\circ} \mathrm{W}$. traverses oriented perpendicular to the strike of the exhalative dolomite (Pl. 1B), which represents the exploration target. A base line oriented N. $16^{\circ}$ E. with $50-\mathrm{m}$ intervals to a length of $650 \mathrm{~m}$, was constructed along the exhalative dolomite. A total of 14 CEM profiles (representing $4.2 \mathrm{~km}$ ) were surveyed along traverse lines that run perpendicular to this base line. A 150-m coil spacing was used for all CEM profiles, except profiles $100 \mathrm{~S}, 150 \mathrm{~S}$, and $200 \mathrm{~S}$, which were surveyed at a $100-\mathrm{m}$ coil spacing; measurements were made at $50-\mathrm{m}$ intervals along all traverses. Only relatively high-frequency $(5,010 \mathrm{~Hz}) \mathrm{CEM}$ fields were used in this survey because of the relatively weak response at lower frequencies. Not all of the grid points were occupied by the CEM surveyors because the terrain in some parts along the CEM profiles was inaccessible. The resulting data gaps are indicated on the accompanying contoured map (PI. 1B) of CEM data points.

\section{CEM Interpretation}

The results of the CEM survey at Farah Garan East (Plate 1B) show very weak responses. The maximum negative tilt-angle reading observed in the whole area is minus $16^{\circ}$, which indicates an absence of highly conductive materials. The results of the CEM measurements were plotted on a map and contoured with a contour interval of 5 degrees of tilt angle (PI. 1B). The contour map of the CEM survey over Farah Garan East shows three weakly anomalous zones (indicated by small negative dip angles).

A negative anomaly in the northern part of the survey area is indicated by negative dip angles of -8 to $-12^{\circ} \mathrm{N}$, between stations $100 \mathrm{E}$ and $100 \mathrm{~W}$ (anomaly A, and profile $250 \mathrm{~N}$ on Plate 1B). This anomaly is associated with a talcose fracture zone in dolomite, that contains minor malachite. A CEM anomaly in the central part of the survey area (area B on P1. 1B) is composed of three subzones: A northwestern subzone that trends northwest through $150 \mathrm{~N}$ at $125 \mathrm{~W}$; a southwestern subzone that trends southwest from $75 \mathrm{~N}$ at $50 \mathrm{~W}$, to $0 \mathrm{~N}$ at $130 \mathrm{~W}$; and an eastern subzone that trends northeast from $50 \mathrm{~N}$ at $25 \mathrm{~W}$, to $100 \mathrm{~N}$ at $25 \mathrm{E}$. These anomalous subzones probably represent intersecting fracture zones. A southernmost negative CEM anomaly lies in the southwestern corner of the CEM grid (area C, Pl. 1B). The negative tilt angles of this zone do not exceed $-8^{\circ}$, but the zone is significant in that it is located over ancient gold workings located along a steeply dipping quartz vein.

Interpretation of the CEM profiles was done by comparing field curves to model test curves by Crone (Crone, 1966). Two field profiles are shown on Plate 1. The wide, weakly negative anomaly located along profile $250 \mathrm{~N}$ is interpreted to indicate the presence of a wide, weak conductor at the surface, as exposed in the ancient working on line $250 \mathrm{~N}$, where a talcose fracture zone in dolomite contains sparsely disseminated ore minerals. CEM profile $150 \mathrm{~N}$ (PI. 1) is interpreted to indicate the presence of a weakly conductive body dipping about $60^{\circ} \mathrm{W}$. Estimated depth to the top of the conductor is about $25 \mathrm{~m}$; this conductor probably is a fault zone, or the intersection of two fault zones, one trending northwest and dipping southwest, and the other trending northeast and dipping northwest.

\section{CEM Conclusion}

The results of the Crone EM survey conducted over the Farah Garan East prospect indicate relatively low CEM responses. The CEM anomaly over the outcropping exhalative dolomite of area $A$ is weak; the maximum anomaly was obtained over ancient workings located along a talcose fracture zone that cuts the dolomite and contains sparsely disseminated ore minerals. The three-lobed anomaly located in the central part of the CEM grid (area B) probably represents intersecting fault zones. The weak anomaly located in the southwest corner of the CEM grid (area C) coincides with a small ancient gold prospect situated on a steeply dipping quartz vein in mafic metavolcanic rocks.

\section{RESULTS OF DRILLING AT FARAH GARAN}

The results of recent drilling at Farah Garan (Doebrich, 1989) provide a comparative basis for estimation of the exploration potential of the Farah Garan East prospect.

At Farah Garan, three lenticular units of exhalative dolomite with associated ore minerals have now been tested by two or more drill holes each. Smith and Mawad (1982) reported a high-grade gold intercept in drill hole FG-3 at the north end of the western exhalative dolomite unit. Four additional holes (FG-7, FG-8, FG-9, and FG-10) drilled across the western exhalative unit penetrated rocks that are relatively barren. At the 
eastern exhalative unit, one old drill hole (FG-1) and one new drill hole (FG-6) both were relatively barren. At the south exhalative unit, two drill holes (FG-4 and FG-5) encountered significantly mineralized intercepts, "estimated to represent approximately $225,000 \mathrm{t}$ containing $2.8 \mathrm{ppm} \mathrm{Au}, 33 \mathrm{ppm} \mathrm{Ag}, 0.9$ percent $\mathrm{Cu}$, and 2.5 percent $\mathrm{Zn}^{n}$ (Doebrich, 1989, p. 1). According to Table 1 of Fernette and Tawil (1984), this is comparable to some of the medium-sized ore bodies at Al Masane, but it has a somewhat higher gold grade and somewhat lower copper and zinc grades. Nevertheless, in the absence of more and bigger orebodies nearby, the small size, low grade, steep dip, and rugged terrain render the known deposits of Farah Garan subeconomic (Doebrich, 1989).

\section{GENERAL CONCLUSIONS}

At Farah Garan East, ore minerals are sparsely and erratically distributed in dolomite (vxd), dolomite-talc breccia (dtbx), carbonate-sericite phyllite (vhs), and carbonate-altered mafic metavolcanic rocks [mv(ca)]. The primary ore minerals are pyrite, tennantite, galena, and sphalerite. The dolomite lenses and associated beds of carbonate-sericite phyllite are concordant with layering in metavolcanic rocks, stratigraphically below and above them. Funnel-shaped bodies of breccia are associated with relatively thick accumulations of dolomite near the north and south ends of the $500-\mathrm{m}$-long zone of dolomite outcrops. Zones of carbonate-altered rocks surround the dolomitic rocks and extend eastward beneath them.

The dolomite lenses of Farah Garan East are interpreted as volcanic-related submarine hot-spring deposits. Dolomite-talc breccia, dolomite breccia, and quartz breccia are interpreted as submarine hot-spring vent breccias. Discordant bodies of carbonate-altered metavolcanic rocks beneath the north and south vent breccias are interpreted as chimney-like hot-spring feeder zones along fracture zones in the subjacent volcanic pile. Other carbonate-altered zones, both concordant and discordant to layering in the metavolcanic rocks probably represent pathways of convective circulation for hydrothermal fluids heated by interaction with cooling volcanic and subvolcanic rocks. Laterally extensive layers of carbonate-sericite phyllite that surround lenses of volcanic-exhalative dolomite probably represent hydrothermally altered felsic volcaniclastic sediments. Surface distributions of ore minerals and gold, silver, copper, lead, zinc, arsenic, antimony, and tellurium geochemical anomalies are small, sparse, and of subeconomic grade.

Weak electromagnetic anomalies indicate that no subsurface bodies of concentrated, conductive ore minerals are present at Farah Garan East.

\section{RECOMMENDATIONS}

No drilling is recommended at Farah Garan East. Recent drilling at Farah Garan has shown that only small, subeconomic concentrations of ore minerals are present there. Ore minerals are much less abundant at the surface of Farah Garan East than at the surface of Farah Garan. Geochemical anomalies at Farah Garan East are small, sparse, and low-grade. Ground EM surveys indicate that no massive concentrations of ore minerals are present in the subsurface at Farah Garan East. Therefore, no drilling target has been defined, and no drilling is recommended.

\section{DATA STORAGE}

All field and laboratory data for this report are stored in Data File USGS-DF-10-9 in the Jeddah office of the U.S. Geological Survey Saudi Arabian Mission. This includes field maps, field notebooks, assay reports, and geophysical data. MODS file 4886 has been updated.

\section{REFERENCES}

Anderson, R.E., 1979, Geology of the Wadi Atf (Sheet 17/43A) and Mayza (Sheet 17/43B) quadrangles, Kingdom of Saudi Arabia: Saudi Arabian Directorate General of Mineral Resources Bulletin 25, 33p., 2 geologic maps, $1: 100,000$ scale.

Bookstrom, A. A., Vennum, W. R., and Doebrich, J. L., 1989, Geology and mineral resources of the Farah Garan - Kutam mineral belt, southeast Asir, Kingdom of Saudi Arabia: Saudi Arabian Directorate General of Mineral Resources Technical Record USGS-TR-10-3.

Conway, C.M., 1984, Geology and regional setting of the Al Masane ancient mine area, southeastern Arabian Shield, Kingdom of Saudi Arabia: Saudi Arabian Deputy Ministry for Mineral Resources Open File Report USGS-OF-04-54, 97p. 
Crone, J. Duncan, 1966, The development of a new ground electromagnetic method for use as a reconnaissance tool: Society of Exploration Geophysicists Mining geophysics case histories, v. 1, pp. 151-156.

Doebrich, J. L., 1989, An evaluation and geochemical survey of the Farah Garan prospect, Kingdom of Saudi Arabia: Saudi Arabian Directorate General of Mineral Resources Technical Record USGS-TR-O9-5,78 p. USGS OF 90-420.

Fernette, G., and Al Tawil, Z.A., 1984, Al Masane: Mining Magazine, v. 150 , no. 6, p. 538-541.

Greenwood, W.R., Stoeser, D.B., Fleck, R.J., and Stacey, J.S., 1982, Late Proterozoic island-arc complexes and tectonic belts in the southern part of the Arabian Shield, Kingdom of Saudi Arabia: Saudi Arabian Deputy Ministry for Mineral Resources Open File Report USGS-OF-02-8, 46 p. USGS OF 83-296.

Kellogg, K.S., Jannadi, Eyad, and El-Komi, M.B., 1989, Follow-up evaluation of 15 geochemically anomalous areas and evaluation of four prospects in the Farah Garan - Kutam mineral belt, Kingdom of Saudi Arabia: Saudi Arabian Directorate General of Mineral Resources Open-File Report USGS-OF-09-10, 21 p. USGS OF $90-4 / 8$.
Parker, T. W. H., 1982, Assessment of the mineral potential of the Kutam - Al Halahila district southeast Asir: Saudi Arabian Deputy Ministry for Mineral Resources Open-File Report RF-OF-02-22, 98 p.

Riofinex Geological Mission, 1978, An investigation of the geology and exploration potential of the Wadi Wassat - Kutam district southeast Asir: Directorate General of Mineral Resources, Open-File Report RF-1978-3, v. 1, 130 p., v. 2, $10 \mathrm{Pl}$, with a reconnaissance geological map of southeast Asir at $1: 100,000$ seale

Samater, R.M., Johnson, P.R., and Bookstrom, A.A., 1989, Reconnaissance geochemical survey of the Farah Garan - Kutam mineral belt, Kingdom of Saudi Arabia: Saudi Arabian Directorate General of Mineral Resources Open-File Report USGS-8F-18-4, 25 p., 1:50,000 scale.

Smith, C.W., 1979, Ancient mines of the Farah Garan area, southwestern Saudi Arabia, with a section on reconnaissance geophysical exploration by H.R. Blank: U.S. Geological Survey Saudi Arabian Mission Project Report 243, SA(IR)-243, 56p. USGS OF 79-1659.

Smith, C. W., and Mawad, M. M., 1982, Drilling results at the Farah Garan ancient mine, southwestern Saudi Arabia: Saudi Arabian Deputy Ministry for Mineral Resources, OpenFile Report USGS-OF-02-04, 47 p.

\begin{abstract}
The work on which this report is based was performed in accordance with a cooperative agreement between the U.S. Geological Survey and the Saudi Arabian Ministry of Petroleum and Mineral Resources. This report is a product of the 1408 DMMR Work Program and is listed as Subproject 3.11.28. The information contained in this report is a product of Ministry work; if the information herein is used in any form, either quoted or paraphrased, this report should be properly cited using the full serial number, the author's name(s), and the date (year) of publication.
\end{abstract}

The correct citation for this report is as follows:

\begin{abstract}
Bookstrom, A.R., El-Komi, M.B., and Christian, R.P., 1989, An evaluation and geochemical survey of the Farah Garan East prospect, southeastern Asir, Kingdom of Saudi Arabia: Saudi Arabian Directorate General of Mineral Resources Open-File Report USGS-OF-10-6 (plate with pamphlet), 15 p., scale 1:2,000.
\end{abstract}

This report was reviewed by Ken Sargeant. It has been edited and reviewed for conformity with U.S. Geological Survey Open-File standards. Product names used in this report are for descriptive purposes only and in no way implies endorsement by the U.S. Geological Survey. 